\title{
COLLECTOR SELECTION FOR SOLAR EJECTOR COOLING SYSTEM
}

\author{
B. J. HUANG ${ }^{\dagger}, *$, V. A. PETRENKO*, I. YA. SAMOFATOV** and N. A. SHCHETININA** \\ *Department of Mechanical Engineering, National Taiwan University, Taipei 106, Taiwan \\ **Odessa State Academy of Refrigeration, Odessa 270026, Ukraine
}

Received 21 September 1999; revised version accepted 27 March 2001

Communicated by BYARD WOOD

\begin{abstract}
The performance of a solar ejector cooling system is simulated using three different collectors: a conventional flat plate collector, a high efficiency flat plate collector and a vacuum-tube collector. It is shown that with the proper selection of the generating temperature an optimum COP can be achieved. The solar ejector cooling system using the single-glazed solar collector with selective surface and an enhanced air insulating layer can be most economical when operated at the optimum generating temperature of the ejector cooling machine. In this case, the solar system cost is around 1 USD per watt of cooling capacity for air conditioning applications. (C) 2001 Published by Elsevier Science Ltd.
\end{abstract}

\section{INTRODUCTION}

A solar cooling/refrigeration system which converts the solar thermal energy into cooling effect has long been an interesting subject for scientists and engineers. In practical application, a solar collector is used to absorb the solar thermal energy first. The heat is then used to drive a heat-driven cooling machine to produce a cooling effect. The total cost of a solar cooling system thus includes the costs of the solar energy collecting system and the heat-driven cooling machine. For a heat-driven cooling machine, the required generating temperature may be high (higher than $80^{\circ} \mathrm{C}$ ). A high-performance vacuum-tube collector with high cost is thus recommended and the total cost of a solar cooling system becomes unacceptable.

Whether a cheaper solar collector like a flatplate collector can be used for a solar cooling system still remains an unresolved question for many researchers. By utilizing a high-quality selective surface, good insulation design and highperformance glass cover, the flat-plate solar collector can be made with relatively high efficiency at low cost. In addition, the efficiency of heatdriven cooling machines has also been improved dramatically. The present study intends to reexamine the feasibility of using less expensive flat-plate solar collectors to provide the energy for a solar cooling system.

'Author to whom correspondence should be addressed. Tel.: +886-2-2363-4790; fax: +886-2-2364-0549; e-mail: bjhuang@tpts6.seed.net.tw

\section{DESIGN OF A SOLAR EJECTOR COOLING SYSTEM}

We have been investigating ejector cooling machines (ECM) using R113 and R142b as the working fluids (Huang et al., 1985; Petrenko and Shchetinina, 1992; Petrenko et al., 1997; Shchetinina et al., 1987a,b). In a recent study, we found that a solar ejector cooling system (SECS) using R141b as the working fluid and utilizing a specially-designed ejector can obtain a better $\mathrm{COP}_{\mathrm{ECM}}$ than before (Huang et al., 1998, 1999; Huang and Chang, 1999). An ECM using R141b as the working fluid is thus chosen for the SECS in the present study. Fig. 1 is the schematic of a single-stage SECS.

A SECS consists of an ECM and the solar collector system. Solar thermal energy is absorbed by the solar collector and used to drive the ECM. The generating temperature $T_{\mathrm{g}}$ of the ECM is usually high $\left(>70^{\circ} \mathrm{C}\right)$ in order to obtain a better performance. The solar collector thus needs to operate at a higher temperature $\left(>80^{\circ} \mathrm{C}\right)$. Vacuum tube solar collectors have been recommended by many researchers for SECS in order to have higher energy collection efficiency at a high inlet temperature. However, the cost is very high. For a SECS which requires the collector to operate at a temperature in the range $80-100^{\circ} \mathrm{C}$, a cheaper flat-plate type collector may be used though its energy collecting efficiency is relatively low.

For a SECS, selection of the design point for condensing temperature $T_{\mathrm{c}}$, evaporating temperature $T_{\mathrm{e}}$ and generating temperature $T_{\mathrm{g}}$ of the ECM is very important. The method of the design of an 


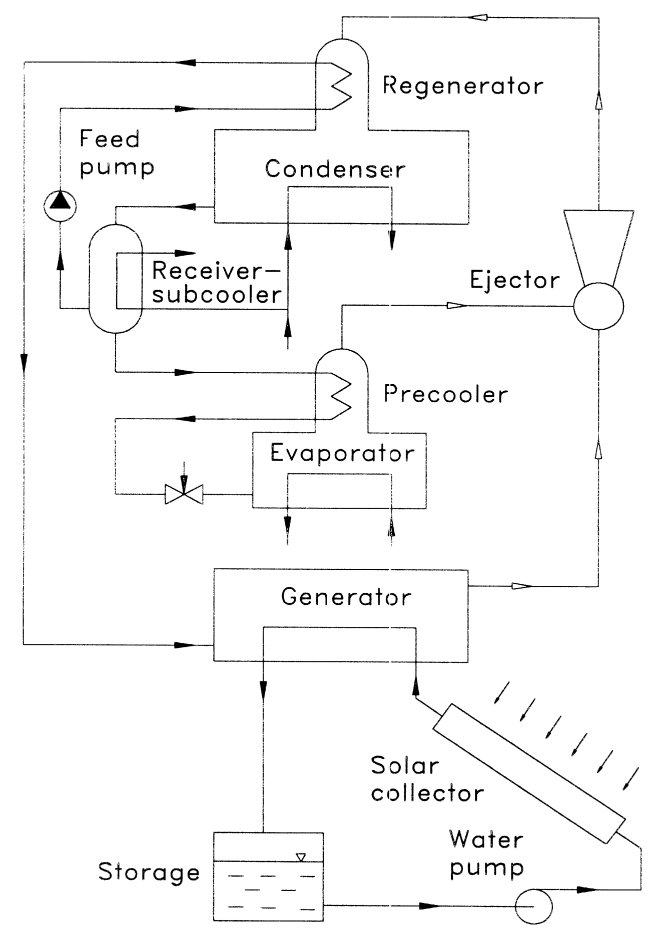

Fig. 1. Schematic diagram of solar ejector cooling system.

ECM using R141b as the working fluid has been studied by Huang et al. (1999) and Huang and Chang (1999). It has been shown that the design parameters of an ejector are dependent on the operating conditions $\left(T_{\mathrm{c}}, P_{\mathrm{c}}, T_{\mathrm{g}}, P_{\mathrm{g}}, T_{\mathrm{e}}, P_{\mathrm{e}}\right)$ which are related to the specific needs of the application and the equipment capability. The evaporation temperature $T_{\mathrm{e}}$ is usually in the range of $5-10^{\circ} \mathrm{C}$ for air conditioning purposes and about -5 or $-6^{\circ} \mathrm{C}$ for refrigeration purposes. The condensing temperature $T_{\mathrm{c}}$ depends both on the heat-rejecting equipment used for the condenser and on the type of the cooling fluid (water or air). For different climatic conditions it spreads over a wide range, usually $28-40^{\circ} \mathrm{C}$. In the present study, the design calculation of a R141b ECM follows the method developed by Huang et al. (1999) and Huang and Chang (1999).

The selection of generating temperature $T_{\mathrm{g}}$ is especially important for SECS since it affects not only the coefficient of performance of the ejectorcooling machine $\left(\mathrm{COP}_{\mathrm{ECM}}\right)$, but also the efficiency of the solar collector $\eta_{\mathrm{sc}}$. An increase in $T_{\mathrm{g}}$ increases the $\mathrm{COP}_{\mathrm{ECM}}$ but decreases the $\eta_{\mathrm{sc}}$. Since the overall efficiency of SECS is the product of the particular coefficients

$\mathrm{COP}_{\mathrm{o}}=\mathrm{COP}_{\mathrm{ECM}} \times \eta_{\mathrm{sc}}$, the optimal $T_{\mathrm{g}}$ that corresponds to a maximum $\mathrm{COP}_{\mathrm{o}}$ is determined in the present study.

\section{SOLAR COLLECTOR SELECTION FOR EJECTOR COOLING SYSTEM}

For the heat supply of SECS we selected three commercially available solar collectors for comparison. Type A is a low-cost specially designed single-glazed flat-plate solar collector with a selective surface. Type B is a conventional singleglazed solar collector with a selective surface. The difference between type A and type B collector lies in the insulation layer design. Type A collector uses a $10-\mathrm{cm}$ layer of air space (insulation) beneath the glass cover. Type $\mathrm{C}$ is a vacuum-tube solar collector with tube-in-sheet fin. The steadystate thermal performance curves of these solar collectors are

$\eta_{\mathrm{sc}}=0.80-C_{\mathrm{A}} \frac{\left(T_{\mathrm{i}}-T_{\mathrm{a}}\right)}{I_{\mathrm{T}}}$,

$C_{\mathrm{A}}=3.5 \frac{\mathrm{m}^{2}}{\mathrm{~W} \mathrm{~K}}($ Type A)

$\eta_{\mathrm{sc}}=0.80-C_{\mathrm{B}} \frac{\left(T_{\mathrm{i}}-T_{\mathrm{a}}\right)}{I_{\mathrm{T}}}$,

$C_{\mathrm{B}}=5.7 \frac{\mathrm{m}^{2}}{\mathrm{~W} \mathrm{~K}}($ Type B $)$

$\eta_{\mathrm{sc}}=0.80-C_{\mathrm{C}} \frac{\left(T_{\mathrm{i}}-T_{\mathrm{a}}\right)}{I_{\mathrm{T}}}$,

$C_{\mathrm{C}}=2.0 \frac{\mathrm{m}^{2}}{\mathrm{~W} \mathrm{~K}}($ Type C$)$

where $I_{\mathrm{T}}$ is the incident solar radiation upon the collector aperture $\left(\mathrm{W} \mathrm{m}^{-2}\right) ; T_{\mathrm{i}}$ and $T_{\mathrm{a}}$ are the collector inlet and the ambient temperatures, respectively. Eqs. (2) and (3) were obtained from testing results of the solar energy lab at the National Taiwan University for the type A and B collectors. Eq. (4) for the type C collector was obtained from the manufacturer.

In the present study, we first determine the COP of an ECM for different climatic conditions $\left(T_{\mathrm{c}}=28-40^{\circ} \mathrm{C}\right)$ in an air conditioning regime $\left(T_{\mathrm{e}}=8^{\circ} \mathrm{C}\right)$ and a refrigeration regime $\left(T_{\mathrm{e}}=-6^{\circ} \mathrm{C}\right)$ for a wide range of generating temperatures $\left(T_{\mathrm{g}}=70-130^{\circ} \mathrm{C}\right)$. The calculation follows the method developed by Huang et al. (1999) and Huang and Chang (1999). The results are shown in Fig. 2.

As seen from Fig. $2 \mathrm{COP}_{\mathrm{ECM}}$ increases with increasing $T_{\mathrm{g}}$ and $T_{\mathrm{e}}$ and with decreasing $T_{\mathrm{c}}$ and 


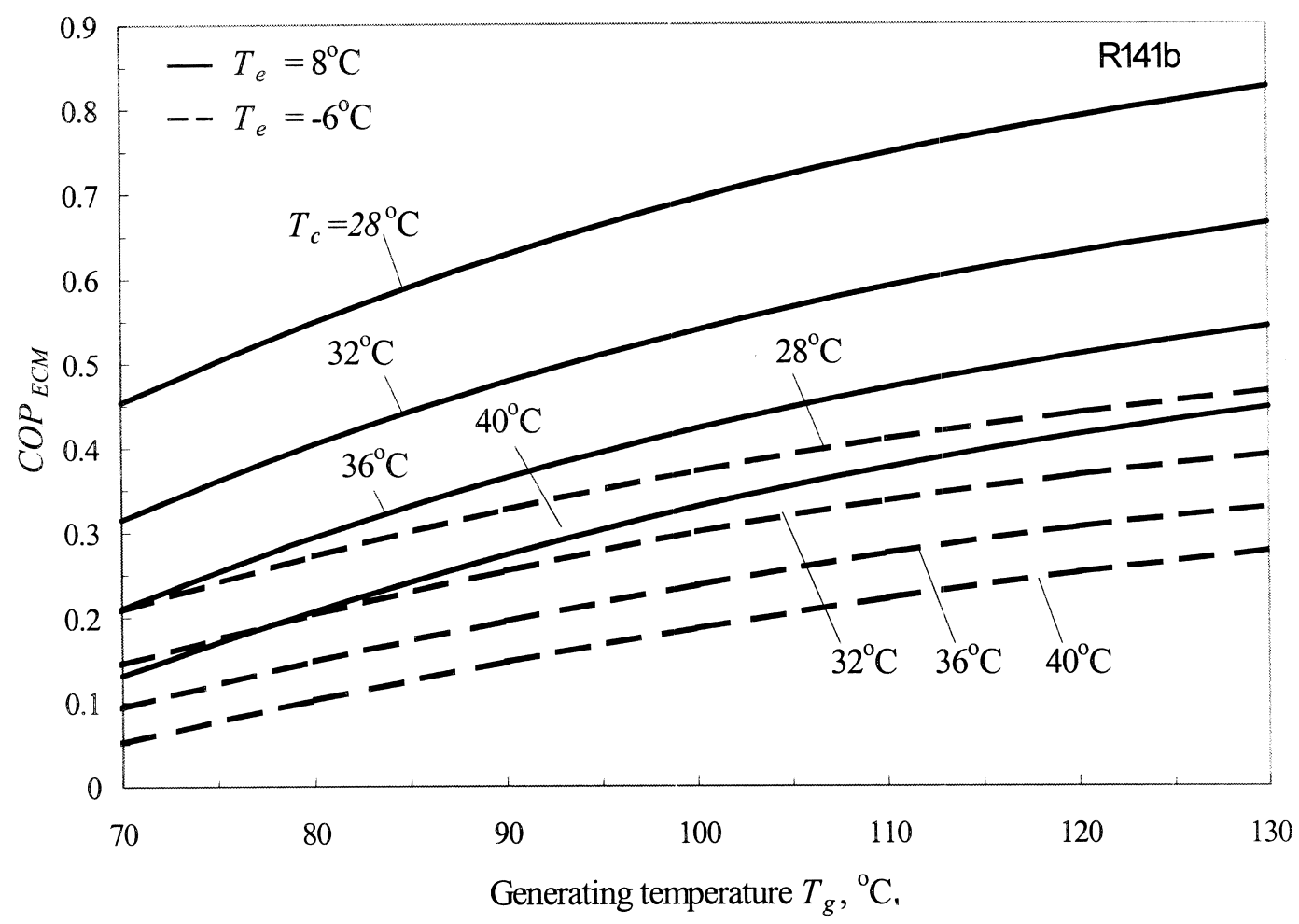

Fig. 2. Variation of $\mathrm{COP}_{\mathrm{ECM}}$ with $T_{\mathrm{g}}$ for $T_{\mathrm{e}}=8^{\circ} \mathrm{C}$ and $T_{\mathrm{e}}=-6^{\circ} \mathrm{C}$ at different $T_{\mathrm{c}}$.

can reach the value 0.7 at $T_{\mathrm{g}}=100^{\circ} \mathrm{C}, T_{\mathrm{c}}=28^{\circ} \mathrm{C}$ and $T_{\mathrm{e}}=8^{\circ} \mathrm{C}$.

According to the performance of the ECM shown in Fig. 2, we then evaluate the perform- ance of a SECS. Comparison between the different types of solar collectors for heat supply of SECS was first made. The solar thermal energy is transported to the generator by a heating medium

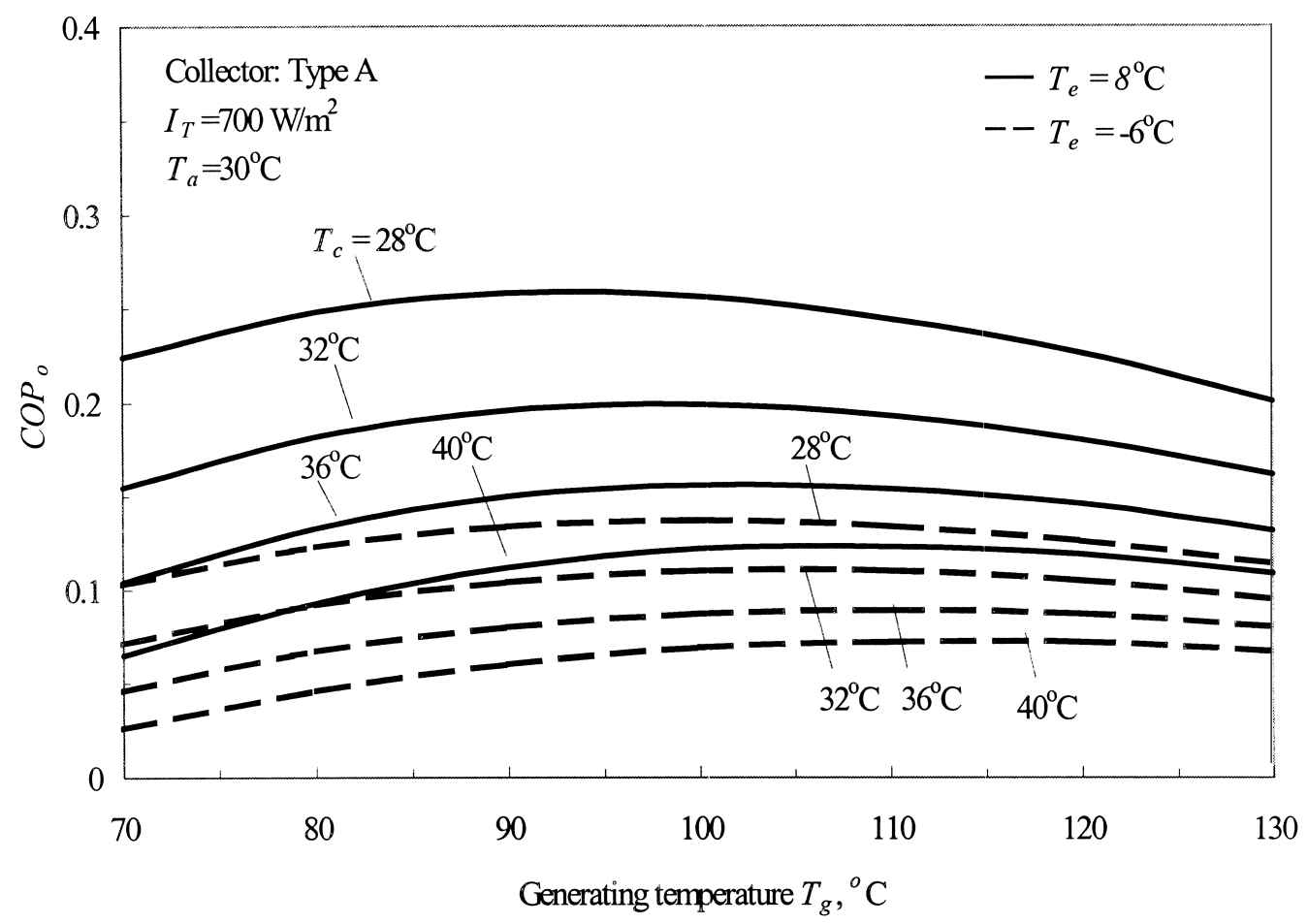

Fig. 3. Variation of $\mathrm{COP}_{\mathrm{o}}$ with $T_{\mathrm{g}}$ for $T_{\mathrm{e}}=8^{\circ} \mathrm{C}$ and $T_{\mathrm{e}}=-6^{\circ} \mathrm{C}$ at different $T_{\mathrm{c}}$ (collector type A). 


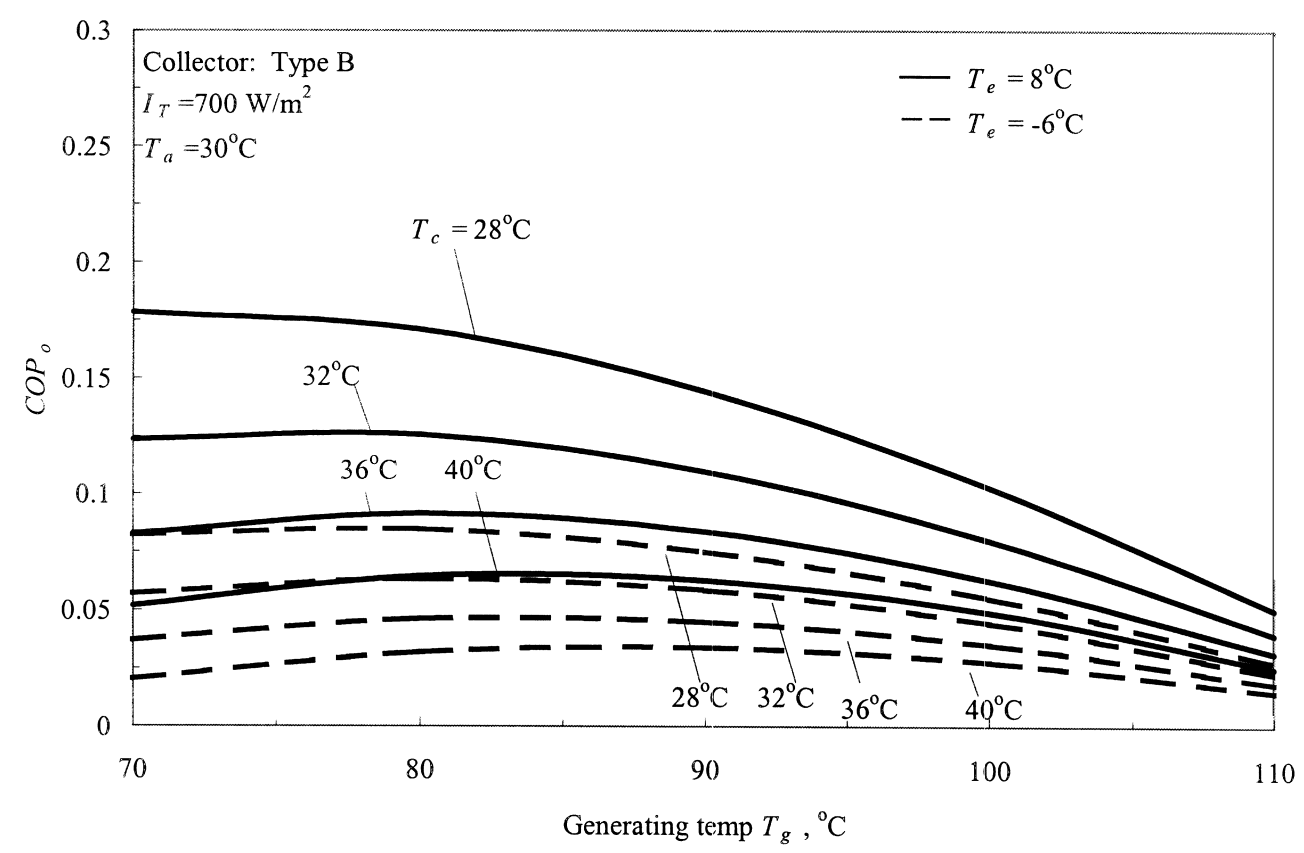

Fig. 4. Variation of $\mathrm{COP}_{\mathrm{o}}$ with $T_{\mathrm{g}}$ for $T_{\mathrm{e}}=8^{\circ} \mathrm{C}$ and $T_{\mathrm{e}}=-6^{\circ} \mathrm{C}$ at different $T_{\mathrm{c}}$ (collector type B).

(water). The inlet temperature of the solar collector was assumed $10^{\circ} \mathrm{C}$ higher than the generating temperature of the ECM, i.e. $T_{\mathrm{i}}=T_{\mathrm{g}}+10^{\circ} \mathrm{C}$. The incident solar radiation is assumed at $I_{\mathrm{T}}=700 \mathrm{~W}$ $\mathrm{m}^{-2}$ and the ambient temperature at $T_{\mathrm{a}}=30^{\circ} \mathrm{C}$. From this, the thermal efficiency of a solar collector $\eta_{\mathrm{sc}}$ can be calculated. The overall COP of the solar cooling system $\mathrm{COP}_{\mathrm{o}}$ is evaluated for a given $T_{\mathrm{g}}, T_{\mathrm{c}}$, and $T_{\mathrm{e}}$, according to Eq. (1). Plotting $\mathrm{COP}_{\mathrm{o}}$ for various $T_{\mathrm{g}}, T_{\mathrm{c}}$, and $T_{\mathrm{e}}$, we can find the optimum design of a SECS.

Figs. 3-5 show the variation of $\mathrm{COP}_{\mathrm{o}}$ with $T_{\mathrm{g}}$ for $T_{\mathrm{e}}=8^{\circ} \mathrm{C}$ and $T_{\mathrm{e}}=-6^{\circ} \mathrm{C}$ at $T_{\mathrm{c}}=28,32,36$ and $40^{\circ} \mathrm{C}$. Each curve on Figs. 3-5 has a maximum value, which corresponds to the optimum generating temperature of the ejector cooling machine.

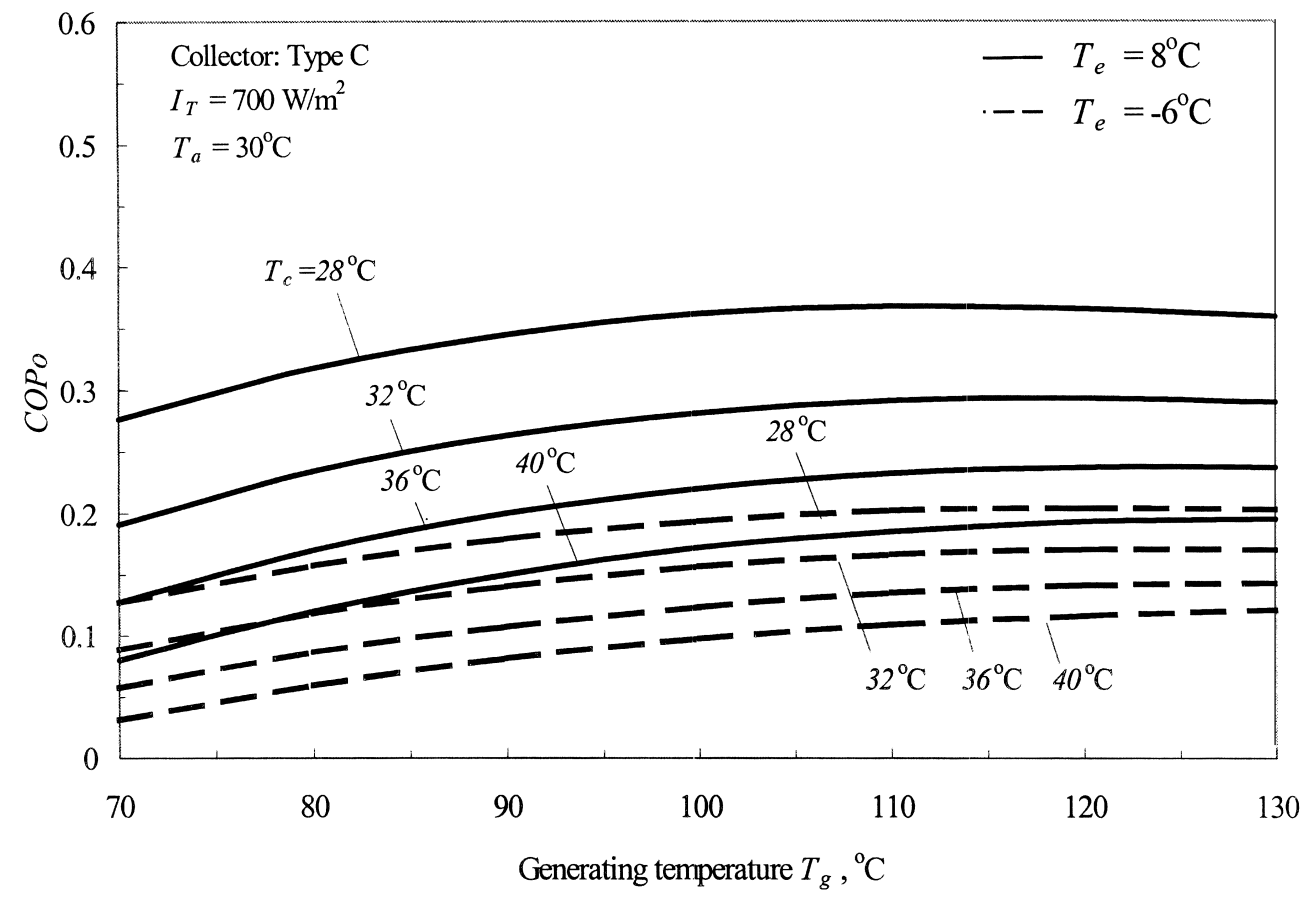

Fig. 5. Variation of $\mathrm{COP}_{\mathrm{o}}$ with $T_{\mathrm{g}}$ for $T_{\mathrm{e}}=8^{\circ} \mathrm{C}$ and $T_{\mathrm{e}}=-6^{\circ} \mathrm{C}$ at different $T_{\mathrm{c}}$ (collector type C). 
Table 1. A solar ejector air-conditioning system using different types of solar collectors

\begin{tabular}{|c|c|c|c|}
\hline Collector type & A & B & $\mathrm{C}$ \\
\hline Cooling capacity, $Q_{\mathrm{e}}(\mathrm{kW})$ & 10 & 10 & 10 \\
\hline Evaporating temperature, $T_{\mathrm{e}}\left({ }^{\circ} \mathrm{C}\right)$ & 8 & 8 & 8 \\
\hline Condensing temperature, $T_{\mathrm{c}}\left({ }^{\circ} \mathrm{C}\right)$ & 32 & 32 & 32 \\
\hline Optimum generating temperature, $T_{\mathrm{g}}\left({ }^{\circ} \mathrm{C}\right)$ & 85 & 70 & 95 \\
\hline Optimum $\mathrm{COP}_{\mathrm{o}}$ & 0.19 & 0.12 & 0.28 \\
\hline Solar collector efficiency, $\eta_{\mathrm{sc}}$ & 0.43 & 0.39 & 0.54 \\
\hline Optimum $\mathrm{COP}_{\mathrm{ECM}}$ & 0.44 & 0.31 & 0.52 \\
\hline Solar collector area, $A_{\mathrm{sc}}\left(\mathrm{m}^{2}\right)$ & 75 & 119 & 51 \\
\hline Solar system cost $C_{\mathrm{S}}$, USD & 10,230 & 14,420 & 24,730 \\
\hline Price of solar system, USD $/ \mathrm{m}^{2}$ & 136 & 121 & 485 \\
\hline$C_{\mathrm{S}} / Q_{\mathrm{e}}, \mathrm{USD} / \mathrm{W}$ cooling capacity & 1.02 & 1.44 & 2.47 \\
\hline
\end{tabular}

Table 2. A solar ejector refrigerating system using different types of solar collectors

\begin{tabular}{|c|c|c|c|}
\hline Collector type & A & $\mathrm{B}$ & $\mathrm{C}$ \\
\hline Cooling capacity, $Q_{\mathrm{e}}(\mathrm{kW})$ & 1.0 & 1.0 & 1.0 \\
\hline Evaporating temperature, $T_{\mathrm{e}}\left({ }^{\circ} \mathrm{C}\right)$ & -6 & -6 & -6 \\
\hline Condensing temperature, $T_{\mathrm{c}}\left({ }^{\circ} \mathrm{C}\right)$ & 32 & 32 & 32 \\
\hline Optimum generating temperature, $T_{\mathrm{g}}\left({ }^{\circ} \mathrm{C}\right)$ & 90 & 75 & 100 \\
\hline Optimum $\mathrm{COP}_{\mathrm{o}}$ & 0.103 & 0.063 & 0.161 \\
\hline Solar collector efficiency, $\eta_{\mathrm{sc}}$ & 0.41 & 0.35 & 0.52 \\
\hline Optimum $\mathrm{COP}_{\mathrm{ECM}}$ & 0.25 & 0.18 & 0.31 \\
\hline Solar collector area, $A_{\mathrm{sc}}\left(\mathrm{m}^{2}\right)$ & 13.9 & 22.7 & 8.9 \\
\hline Solar system cost $C_{\mathrm{S}}$, USD & 1895 & 2752 & 4315 \\
\hline Price of solar system, USD $/ \mathrm{m}^{2}$ & 136 & 121 & 485 \\
\hline$C_{\mathrm{S}} / Q_{\mathrm{e}}, \mathrm{USD} / \mathrm{W}$ cooling & 1.90 & 2.75 & 4.32 \\
\hline
\end{tabular}

The optimum $\mathrm{COP}_{\mathrm{o}}$ decreases with increasing $T_{\mathrm{c}}$ and decreasing $T_{\mathrm{e}}$. It can be seen that, for obtaining a higher solar collector efficiency, $T_{\mathrm{g}}$ can be chosen at a temperature about 10 to $15^{\circ} \mathrm{C}$ lower than the corresponding optimum values with only very little effect on the optimum $\mathrm{COP}_{\mathrm{o}}$.

The total installation cost of the solar collector system is estimated. Table 1 shows the SECS for air-conditioning application at a fixed cooling capacity $(10 \mathrm{~kW})$. It is interesting to note that, with a proper selection of the generating temperature, an optimum $\mathrm{COP}_{\mathrm{ECM}}$ can be determined. For the flat-plate collectors (type A and type B), $\eta_{\mathrm{sc}}$ makes little difference (0.43 against 0.39$)$ but $\mathrm{COP}_{\mathrm{ECM}}$ makes a larger difference (0.44 against $0.31)$. Though $\eta_{\mathrm{sc}}$ and $\mathrm{COP}_{\mathrm{ECM}}$ are higher $(0.54$ and 0.52 , respectively) for a SECS using the solar collector type $\mathrm{C}$, the cost of the vacuum-tube solar collector (type $\mathrm{C}$ ) is very high. The unit cost of a solar system $C_{\mathrm{S}} / Q_{\mathrm{e}}$ using type $\mathrm{C}$ collector becomes the highest.

It is shown that the SECS using type A collector is most economical. The unit solar cooling system cost is around 1 USD per watt of cooling capacity.

Table 2 shows the case of a SECS for the refrigeration application. It shows again that the SECS using type A collector is most economical. The unit cost of the solar system $C_{\mathrm{S}} / Q_{\mathrm{e}}$ for the refrigeration application is about one time higher than that for the air-conditioning application.
The collector efficiency values in Tables 1 and 2 were calculated from Eqs. (2)-(4) using the inlet temperature $T_{\mathrm{i}}=T_{\mathrm{g}}+10^{\circ} \mathrm{C}$.

\section{DISCUSSION AND CONCLUSION}

In the present paper, we have shown that a SECS using conventional single-glazed solar collector with selective surfaces can be most economical by a proper choice of optimum generating temperature of the ECM. In this case, for the optimum generating temperature in the range 85$90^{\circ} \mathrm{C}$, the solar collector efficiency can reach $0.43-0.41$ and the overall COP $_{0}$ of a SECS reaches about 0.19 for air conditioning purposes and 0.10 for refrigeration purposes. The solar system cost is around 1 USD per watt of cooling capacity in air conditioning applications. The unit system cost $C_{\mathrm{S}} / Q_{\mathrm{e}}$ for refrigeration applications is about one time bigger than that for the air-conditioning application.

\section{NOMENCLATURE}

\footnotetext{
$A_{\mathrm{sc}} \quad$ total solar collector area, $\mathrm{m}^{2}$

$C_{\mathrm{S}} \quad$ solar collector cost, USD

$I_{\mathrm{T}} \quad$ solar radiation intensity incident upon collector aperture, $\mathrm{W} \mathrm{m} \mathrm{m}^{-2}$

$Q_{\text {e }} \quad$ cooling capacity, $\mathrm{kW}$

$T_{\mathrm{a}} \quad$ ambient temperature to collector, ${ }^{\circ} \mathrm{C}$

$T_{\mathrm{c}}^{\mathrm{a}} \quad$ critical condensing temperature of ejector cooling machine, ${ }^{\circ} \mathrm{C}$
} 
$T_{\mathrm{e}} \quad$ evaporating temperature of ejector cooling machine, ${ }^{\circ} \mathrm{C}$

$T_{\mathrm{g}} \quad$ generating temperature of ejector cooling machine, ${ }^{\circ} \mathrm{C}$

$T_{\mathrm{i}} \quad$ inlet temperature to collector, ${ }^{\circ} \mathrm{C}$

$\mathrm{COP}_{\mathrm{o}} \quad$ coefficient of performance of solar cooling system (=cooling power/solar energy input), dimensionless

$\mathrm{COP}_{\mathrm{ECM}}$ coefficient of performance of ejector cooling machine (=cooling power/heat energy input), dimensionless

$\eta_{\mathrm{sc}}$ thermal efficiency of solar collector, dimensionless

Acknowledgements - The present study was supported by the National Science Council of ROC, Taiwan, through grant no. NSC88-2212-E-002-051.

\section{REFERENCES}

Huang B. J., Chang J. M., Petrenko V. A. and Zhuk K. B. (1998) A solar ejector cooling system using refrigerant R-141b. Solar Energy 64(4-6), 223-226.
Huang B. J., Chang J. M., Wang C. P. and Petrenko V. A. (1999) A 1-D analysis of ejector performance. Int. J. Refrig. 22, 354-364.

Huang B. J. and Chang J. M. (1999) Empirical correlation for ejector design. Int. J. Refrig. 22, 379-388.

Huang B. J., Jiang C. B. and Hu F. L. (1985) Ejector performance characteristics and design analysis of jet refrigeration system. ASME J. Eng. Power 107, 792-802.

Petrenko V. A. and Shchetinina N. A. (1992) A solar vapor ejector refrigerator testing in air conditioning regime. In Proceedings World Renewable Energy Congress, September 13-18, Reading, UK, pp. 1023-1029.

Petrenko V. A., Bulavin I. V. and Samofatov I. Y. (1997) Investigation of the methods increasing the efficiency of solar ejector cooling and refrigeration systems. In Proceedings ISES 1997 Solar World Congress, August 24-30, Tajeon, Korea, Vol. 4, pp. 330-341.

Shchetinina N. A., Zhadan S. Z. and Petrenko V. A. (1987a) Experimental investigation of a solar ejector Freon refrigerating machine. Geliotekhnika 23(3), 66-69.

Shchetinina N. A., Zhadan S. Z. and Petrenko V. A. (1987b) Comparison of the efficiency of various ways of heating the generator of a solar ejector Freon refrigerating machine. Geliotekhnika 23(4), 71-74. 